\title{
EFFECT OF HIGH LEVELS OF CHOLECALCIFEROL ON PERFORMANCE, SOME BLOOD CONISTITENTS, BONE QUALITY AND MINERAL RETENTION IN BROILER CHICKS FED LOW LEVELS OF CALCIUM AND PHOSPHORUS \\ Thabet, H. A.; H. A. El-Alaily; S. A. Ibrahim and S. El-Faham Department of Poultry Production, Faculty of Agriculture, Ain Shams university, Shoubra El-Kheima, Cairo, Egypt
}

\section{ABSTRACT}

A 6-wk feeding trail with 216 unsexed day-old Hubbard chicks was conducted to study the effects of supplementing extra levels (3000 vs. 7000 and 8000 I.U) of cholecalciferol on performance, bone quality and mineral retention in broiler chicks fed suboptimal levels of calcium and non-phytate phosphorus $(0.5 \% \mathrm{Ca}$ and $0.25 \%$ NPP). A control diet containing recommended levels of $\mathrm{Ca}$, NPP and cholecalciferol $(1 \%$, $0.5 \%$ and 3000 I.U, respectively). Each diet was fed ad libitum to 6 replicates containing 9 chicks in each.

The results indicated that:

1- Productive performance (body weight, body weight gain, feed consumption and feed conversion ratio) didn't affected significantly $(P \leq 0.05)$ by inclusion deficient $\mathrm{Ca}$ and NPP diets with high levels of cholecalciferol.

2-Plasma $\mathrm{Ca}$ and $\mathrm{P}$ weren't influenced significantly $(\mathrm{P} \leq 0.05)$ by the reduction of $\mathrm{Ca}$ and $P$ with extra levels of cholecalciferol.

3- Dry tibia weight, tibia ash\%, tibia $\mathrm{Ca}$ and $\mathrm{P}$ weren't significantly affected by reducing dietary levels of $\mathrm{Ca}$ and NPP with high levels of cholecalciferol.

4- Birds fed extra levels of cholecalciferol (7000 or 8000 I.U) retain more $\mathrm{Ca}$ and $\mathrm{P}$ as percentage of intake compared with control birds with significant differences $(\mathrm{P} \leq 0.05)$

In conclusion, we recommended that higher levels of cholecalciferol supplementation to low $\mathrm{Ca}$ and NPP diet improved the performance, bone quality and minerals retention in order to reduce phosphorus pollution as well as feed cost.

Keywords: Bone quality, low calcium, low phosphors, cholecalciferol, growth, broiler chicks.

\section{INTRODUCTION}

Phosphorus $(\mathrm{P})$ from plant feed ingredients is not completely available for chicken due to its complex bond with inositol and divalent cations like $\mathrm{Ca}$, $\mathrm{Mg}, \mathrm{Cu}, \mathrm{Zn}, \mathrm{Fe}, \mathrm{Mn}$, etc. The complex is called as phytate. Therefore, inverse relation exists between dietary phytate and the solubility/ availability of these minerals to poultry (Nwokola and Bragg, 1977; Eardman, 1979; Kornegay et al., 1996). Use of plant feed ingredients in chicken diet, result in excretion of $P$ and other minerals bound with phytate in considerable quantities and cause environmental pollution. Dietary calcium $(\mathrm{Ca})$ and $\mathrm{P}$ at their recommended concentrations is known to reduce the utilization of PP (Ballam et al.,1985; Schoner et al., 1993; Qian et al., 1994). The evidence of increased PP availability from plant feed ingredients at their sub-optimal concentrations of $P$ (Davies et al., 1970 ; Onyango et al., 2006 ), existence of gut mucosal phytase activity (Bitar and Reinhold, 1972 ; Onyango et al., 2001) and its enhancement with D3 supplementation (Onyango et al., 2006) reducing cost 
of supplemented $\mathrm{P}$ (inorganic phosphorus) and minimizing phosphorus excretion (Rama Rao et al., 2006b; 2007) . Dietary cholecalciferol has long been known to increased phytate phosphors digestibility and reduce the rachitogenic nature of low-ca, high phytate diets (Mellanly, 1950; Steenlock and Heirting, 1955). The purpose of this study was to examine whether increased dietary cholecalciferol in deficient $\mathrm{Ca}$ and $\mathrm{P}$ broiler diet would equivalent to recommended $\mathrm{Ca}$ an NPP diet to recover performance and bone quality demands.

\section{MATERIALS AND METHODS}

The present study was carried out at the poultry nutrition farm, Poultry Production Department, Faculty of Agriculture, Ain Shams University.

Two hundred and sixteen unsexed one day - old of Hubbard broiler chicks were randomly distributed into 4 treatments. Each treatment comprised of 54 chicks which divided into 6 replicates of 9 chicks each. The chicks were reared $p$ to 6 weeks of age in wire-floored batteries. The control diet (T1) was formulated according to the manual guide of Hubbard broiler chicks which containing calcium 1\%, available phosphorus $0.5 \%$ and 3000 I.U cholecalciferol at the starter period and for other period grower (ca $1 \%$, A.P0.5\%) and finisher (ca $0.9 \%, A . P 0.45 \%$ ) with the same level of cholecalciferol. Then tested diets were containing the half of calcium and available phosphorus requirements with graded levels of cholecalciferol 3000 (T2), 7000 (T3) and 8000 (T4) International unite (IU). All diets were iso calorie and iso nitrogen, experimental diets were listed in (Table 1).

All birds were reared under similar environmental, managerial and hygienic conditions. Feed and water were provided ad libitum. Vaccination programs were applied according to the scheme of vaccination, used in the laboratory.

Body weight and feed consumption were recorded weekly. Weight gain, feed conversion ratio (gain/feed) were calculated weekly.

The total excreta were excreta were collected at 28 and 42 days, feed consumption was recorded during the same period. The excreta sample were dried in a $70^{\circ} \mathrm{C}$ oven, grounded and stored until analysis.

At 28 and 42 days of age, six birds from each treatment (one from each replicate) having average body weight around the treatment were selected and sacrificed by cervical dislocation. Blood sample were taken.

Tibia of both legs were removed, cleaned of flesh and all soft tissue, oven-dried and dry tibia weight, length, breaking strength were determined. The tibias were ground for procedure of the chemical analysis.

The excreta and tibia samples were dried at $105^{\circ} \mathrm{C}$ until constant weight, ashed at $600^{\circ} \mathrm{C}$ for 4 hour, dissolved by using $3 \mathrm{~N} \mathrm{HCl}$, and then filtered. Calcium and phosphorus content were then assayed in the filtrate by a colorimetric method pursuant to AOAC (1990). Apparent retention (percentage of intake) of $\mathrm{Ca}$ and $\mathrm{P}$ were calculated for each treatment.

Blood sample were immediately centrifuged at $3000 \mathrm{rpm}$ for 10 minutes to separate plasma. Plasma calcium, phosphorus and alkaline phosphatase were assayed by colorimetric method using commercial kits of Spinreact Company, Spain. 
Table (1): Composition and calculated analysis of Control and tested diets of first and second experiment.

\begin{tabular}{lcccccc}
\hline & \multicolumn{2}{c}{$\begin{array}{c}\text { Starter } \\
\text { One day to 14 d. }\end{array}$} & \multicolumn{2}{c}{$\begin{array}{c}\text { Grower } \\
\text { 15 to 28 d. }\end{array}$} & \multicolumn{2}{c}{$\begin{array}{c}\text { Finisher } \\
\text { 29 to 42d. }\end{array}$} \\
\hline Ingredients (\%) & Control & Tested & Control & Tested & Control & Tested \\
\hline Yellow corn & 56.10 & 56.92 & 59.51 & 60.24 & 62.16 & 62.91 \\
Soy bean meal (44\%) & 28.80 & 33.31 & 26.30 & 31.10 & 23.10 & 27.4 \\
Corn gluten meal (62\%) & 9.00 & 5.8 & 7.10 & 3.64 & 7.40 & 4.3 \\
Soy oil & 1.46 & 1.46 & 2.6 & 2.6 & 3.32 & 3.32 \\
Limestone & 1.60 & 0.77 & 1.72 & 0.82 & 1.58 & 0.63 \\
Monocalcium phosphate & 1.85 & 0.62 & 1.65 & 0.55 & 1.4 & 0.45 \\
\#Vit. and min premix & 0.30 & 0.30 & 0.30 & 0.30 & 0.30 & 0.30 \\
Salt (NaCl) & 0.25 & 0.25 & 0.25 & 0.25 & 0.25 & 0.25 \\
DL - Methionine & 0.25 & 0.27 & 0.25 & 0.28 & 0.19 & 0.22 \\
HCl lysine & 0.39 & 0.30 & 0.32 & 0.22 & 0.30 & 0.22 \\
@Calculated analysis: & & & & & & 3200 \\
ME kcal/kg & 3000 & 3003 & 3103 & 3103 & 3200 & 3206 \\
Cp (\%) & 23.02 & 23.00 & 21.03 & 21.06 & 20.03 & 20.06 \\
Ca (\%) & 1.00 & 0.50 & 1.00 & 0.50 & 0.90 & 0.45 \\
*Av. ph (\%) & 0.50 & 0.25 & 0.45 & 0.23 & 0.40 & 0.20 \\
Methionine & 0.66 & 0.66 & 0.62 & 0.62 & 0.55 & 0.56 \\
Methionine + cystine (\%) & 1.05 & 1.05 & $0 . .98$ & 0.98 & 0.90 & 0.90 \\
Lysine (\%) & 1.40 & 1.40 & 1.25 & 1.25 & 1.15 & 1.15 \\
\hline
\end{tabular}

\# Each $3 \mathrm{~kg}$ of premix containing: 15000000 I.U VIT. A, $50 \mathrm{~g}$. VIT. E, $3000 \mathrm{mg}$. VIT. K3, 3000 mg. VIT. B1, $8000 \mathrm{mg}$. VIT. B2, $4000 \mathrm{mg}$. VIT. B6, $20 \mathrm{mg}$. VIT. B12, $15000 \mathrm{mg}$ Pantothenic acid, $60000 \mathrm{mg}$. Niacin, $1500 \mathrm{mg}$. Folic acid, $200 \mathrm{mg}$. Biotin, $200000 \mathrm{mg}$ vitC, $700 \mathrm{gm}$. Choline chloride, $80 \mathrm{gm}$. Mn, $80 \mathrm{gm}$. Zn, $60 \mathrm{gm}$. Iron, $10 \mathrm{gm}$. Cu, $1 \mathrm{gm}$. lodine, and $0.2 \mathrm{gm}$. Selenium, where $\mathrm{CaCo}_{3}$ was taken as a carrier up to $3 \mathrm{~kg}$, the inclusion rate was $3 \mathrm{~kg}$ premix / Ton feed.

@ Calculated analysis of the experimental diets were done according to (NRC, 1994).

* Calculated on basis average available phosphorus in plant feedstuffs equal $30 \%$ of total phosphorus (NRC, 1994)

Data of concerned traits were subjected to one - way analysis of variance with levels of CC used as the main effect using General Linear Model (GLM) procedure of SAS user's Guide (1995) according to the following model:

$Y_{i k}=\mu+C_{i}+e_{i k}$. Where; $\mu=$ overall mean, $C_{i}=$ levels of cholecalciferol, e $i_{k}=$ experimental error. Individual effects of cholecalciferol levels were compared using Duncan's multiple range tests (1955) at a level equal to 0.05 or 0.01 .

\section{RESULTS AND DISCSSION}

\section{Growth performance}

Table 2 shows the results of body weight, body weight gain, feed consumption, feed conversion ratio and mortality number during the different periods. The overall results indicated that supplementations cholecalciferol in deficient $\mathrm{Ca}$ and $\mathrm{P}$ diets have a significant effect on performance traits, while the differences between birds fed 7000 or 8000 I.U and birds fed control diets didn't reach to significant case.

Birds fed control diet recorded the best body weight compared with 3000,7000 and 8000 I.U (2199, 1886, 2152 and 2180g).These results were agreed with finding of Rio Garcia et al., (2006), (Rama Rao et al., 2008) and 
Haq Nawaz et al. (2008) who found that addition of cholecalciferol in deficient $\mathrm{Ca}$ and $\mathrm{P}$ diets improve body weight as well as body weight gain.

Dietary cholecalciferol has a significant positive effect on feed consumption and feed conversion ratio, birds fed either control diet or 7000 and $8000 \mathrm{I} . \mathrm{U}$ get the best values compared with $3000 \mathrm{I}$.U. These results were in harmony with those observed by Papeosva et al. (2008) and Haq Nawaz et al. (2008).

Table (2): Effect of low levels of Calcium and phosphorus with different levels of Cholecalciferol on broiler productive performance.

\begin{tabular}{|c|c|c|c|c|c|}
\hline Items & Control & 3000 I.U & 7000 I.U & 8000 I.U & Sig. \\
\hline \multicolumn{6}{|c|}{ Body weight (g) } \\
\hline Initial & $42.82 \pm 1.56$ & $42.56 \pm 1.86$ & $42.93 \pm 1.63$ & $42.57 \pm 1.22$ & NS \\
\hline 2 weeks & $398.65 \pm 4.36$ & $353.77 \pm 4.25$ & $386.29 \pm 4.89$ & $394.32 \pm 4.32$ & $\star *$ \\
\hline 4 weeks & $1185.3^{a} \pm 33.36$ & $1005.4^{b} \pm 55.32$ & $1118.4^{a} \pm 38.57$ & $1165.6^{a} \pm 40.57$ & * \\
\hline 6 weeks & $\begin{array}{c}2199^{a} \pm 15.32 \\
(100)\end{array}$ & $\begin{array}{c}1886^{\mathrm{b}} \pm 17.23 \\
(85.7) \\
\text { Body weight gai }\end{array}$ & $\begin{array}{l}2152^{a} \pm 22.48 \\
(97.8) \\
(g)\end{array}$ & $\begin{array}{c}2180 .{ }^{a} \pm 25.12 \\
(99.1)\end{array}$ & * \\
\hline $0-2$ week & $355.83 \pm 3.28$ & $293.17 \pm 3.51$ & $343.36 \pm 3.78$ & $351.75 \pm 3.61$ & * \\
\hline 2-4 week & $786.71^{a} \pm 7.31$ & $651.61^{b} \pm 8.28$ & $732.10^{\mathrm{a}} \pm 8.54$ & $771.25^{\mathrm{a}} \pm 7.11$ & * \\
\hline 4-6 week & $1013.88^{a} \pm 10.52$ & $880.63^{b} \pm 10.02$ & $1033.97^{a} \pm 12.57$ & $1014.68^{a} \pm 12.32$ & * \\
\hline 0-6 week & $2156.4^{a} \pm 10.51$ & $1843.4^{b} \pm 10.54$ & $2109.4^{a} \pm 10.47$ & $2137.7^{a} \pm 10.10$ & * \\
\hline \multicolumn{6}{|c|}{ Feed consumption $(\mathrm{g} /$ bird $)$} \\
\hline $0-2$ week & $452.32 \pm 2.11$ & $467.25 \pm 1.51$ & $460.24 \pm 2.41$ & $459.94 \pm 1.68$ & NS \\
\hline 2-4 week & $1294.78 \pm 8.85$ & $1356.14 \pm 9.68$ & $1321.24 \pm 8.86$ & $1310.30^{\mathrm{b}} \pm 8.65$ & NS \\
\hline 4-6 week & $2074.26 \pm 11.55$ & $2175.03 \pm 11.50$ & $2098.97 \pm 11.89$ & $2129.00 \pm 11.12$ & NS \\
\hline 0-6 week & $\begin{array}{c}3821.4^{b} \pm 11.55 \\
(100)\end{array}$ & $\begin{array}{c}3998.4^{a} \pm 11.55 \\
(104.6)\end{array}$ & $\begin{array}{c}3880.4^{b} \pm 11.55 \\
(101.5)\end{array}$ & $\begin{array}{c}3899.2^{\mathrm{b}} \pm 11.55 \\
(102)\end{array}$ & ** \\
\hline \multicolumn{6}{|c|}{ Feed conversion ratio (g feed / g gain ) } \\
\hline $0-2$ week & $1.27^{\mathrm{b}} \pm 0.02$ & $1.59^{\mathrm{a}} \pm 0.05$ & $1.34^{\mathrm{b}} \pm 0.03$ & $1.30^{\mathrm{b}} \pm 0.07$ & ** \\
\hline 2-4 week & $1.64^{\mathrm{b}} \pm 0.08$ & $2.07^{a} \pm 0.08$ & $1.80^{\mathrm{b}} \pm 0.10$ & $1.69^{\mathrm{b}} \pm 0.10$ & * \\
\hline 4-6 week & $2.04^{\mathrm{b}} \pm 0.08$ & $2.46^{a} \pm 0.08$ & $2.03^{b} \pm 0.10$ & $2.09^{b} \pm 0.10$ & * \\
\hline 0-6 week & $\begin{array}{c}1.77^{\mathrm{b}} \pm 0.10 \\
(100)\end{array}$ & $\begin{array}{c}2.17^{a} \pm 0.10 \\
(122.6)\end{array}$ & $\begin{array}{c}1.84^{b} \pm 0.10 \\
(103.9)\end{array}$ & $\begin{array}{c}1.82^{\mathrm{b}} \pm 0.10 \\
(102.8)\end{array}$ & * \\
\hline $\begin{array}{l}\text { Mortality } \\
\text { number }\end{array}$ & 1 & 1 & 0 & 1 & \\
\hline
\end{tabular}

$\overline{a, b, c, d}$ Means within the same row with different superscripts are significant1y different at $P<0.05$, Sig.= Significance, NS= Non Significant, * $(P \leq 0.05),{ }^{* *}(P \leq 0.01)$.

\section{Blood parameter}

Table 3 shows values of blood $\mathrm{Ca}, \mathrm{P}$ and alkaline phosphatase, dietary cholecalciferol has a significant effects on blood parameter ( $\mathrm{Ca}, \mathrm{P}$ and alkaline phosphatase). It was clear that birds fed deficient calcium and phosphorus diets supplemented with high concentration of cholecalciferol (7000 and 8000 I.U) gave values practically like control group, Plasma calcium of birds fed control, 7000 and 8000 I.U were 11.121, 10.923 and $11.042 \mathrm{mg} / \mathrm{dl}$ respectively without any significant differences. On the other hand, birds fed deficient calcium and phosphorus with 3000 I.U cholecalciferol get the less value $(7.121 \mathrm{mg} / \mathrm{dl})$ with significant difference against all treatments. The same trend was observed in plasma phosphorus. Alkaline phosphatase values in birds fed deficient diet were higher than control, but the differences between 8000 I.U and control group wasn't significant. These results were in agreement with those found by Rama Rao 
et al. (2006), Bolu et al. (2006) and Lofton and Soares (1986) who found that decreasing dietary calcium and phosphorus did not affect plasma calcium, phosphorus and alkaline phosphatase activity in diets containing extra levels of cholecalciferol.

Table (3): Effect of low levels of Calcium and Phosphorus with different levels of Cholecalciferol on some blood constituents.

\begin{tabular}{|c|c|c|c|c|c|}
\hline Items & Control & 3000 I.U & 7000 I.U & 8000 I.U & Sig. \\
\hline & & Calcium (mg/ & & & \\
\hline 4 week & $9.965^{\mathrm{a}} \pm 0.41$ & $6.233^{b} \pm 0.41$ & $9.412^{\mathrm{a}} \pm 0.42$ & $9.745^{\mathrm{a}} \pm 0.45$ & * \\
\hline 6 week & $11.121^{\mathrm{a}} \pm 0.81$ & $\begin{array}{c}7.121^{\mathrm{b}} \pm 0.82 \\
\text { Phosphorus (m }\end{array}$ & $\begin{array}{l}10.923^{a} \pm 0.82 \\
\mathrm{~g} / \mathrm{dl})\end{array}$ & \pm 0.81 & * \\
\hline $\begin{array}{l}4 \text { week } \\
6 \text { week }\end{array}$ & $\begin{array}{r}5.785^{\mathrm{a}} \pm 0.12 \\
6.088^{\mathrm{a}} \pm 0.12 \\
\text { Alka }\end{array}$ & $\begin{array}{r}3.333^{\mathrm{b}} \pm 0.12 \\
4.021^{\mathrm{b}} \pm 0.23 \\
\text { aline Phosphata }\end{array}$ & $\begin{array}{l}5.423^{\mathrm{a}} \pm 0.12 \\
5.896^{\mathrm{a}} \pm 0.21 \\
\text { se }(\mathrm{U} / \mathrm{dl})\end{array}$ & $\begin{array}{l}5.531^{\mathrm{a}} \pm 0.12 \\
5.996^{\mathrm{a}} \pm 0.19\end{array}$ & * \\
\hline $\begin{array}{l}4 \text { week } \\
6 \text { week }\end{array}$ & $\begin{array}{l}1.855^{\mathrm{c}} \pm 0.08 \\
2.022^{\mathrm{c}} \pm 0.16\end{array}$ & $\begin{array}{l}5.232^{\mathrm{a}} \pm 0.09 \\
7.121^{\mathrm{a}} \pm 0.16\end{array}$ & $\begin{array}{l}3.063^{\mathrm{b}} \pm 0.08 \\
3.211^{\mathrm{b}} \pm 0.21\end{array}$ & $\begin{array}{c}2.911^{b} \pm 0.08 \\
3.101^{b c} \pm 0.27\end{array}$ & * \\
\hline
\end{tabular}

a, $b, c$ Means within the same row with different superscripts are significantly different at $P<0.05$, Sig. = Significance, NS= Not significant, * $(P \leq 0.05)$, ** $(P \leq 0.01)$.

\section{Bone quality}

Data in Table 4 showed that increasing dietary cholecalciferol has a significant positive effect on bone quality measurements. Birds fed either 7000 or 8000 I.U gave the best values compared with 3000 I.U. Control birds get the superior values but the differences between control and 7000 or 8000 weren't significant. Tibia length of birds fed control diet was the best during 4 and 6 weeks of age but the differences with either 7000 or 8000 I.U weren't significant. While birds fed deficient diet with 3000 I.U was the worst on among all treatments with significant differences. The same trend was observed in Tibia width and tibia breaking strength. These results were in harmony with those found by Edwards (2002) who found that Supplemental $D_{3}$ appeared to prevents incidence of rickets and improves the bone ash contents, and Baker et al. (1998) who found that with a $D_{3}$ concentration of 1250 micro $\mathrm{g} / \mathrm{kg}$ (250 times the recommended by the NRC) bone ash was increased $(p<0.05)$.

Table (4): Effect of low levels of Calcium and Phosphors with different levels of Cholecalciferol on Bone quality parameters at 4 and 6 weeks of age.

\begin{tabular}{|c|c|c|c|c|c|}
\hline Items & Control & 3000 I.U & 7000 I.U & 8000 I.U & Sig. \\
\hline \multicolumn{6}{|c|}{ Tibia Length $(\mathrm{Cm})$} \\
\hline 4 week & $8.96^{a} \pm 0.07$ & $5.14^{b} \pm 0.07$ & $8.45^{\mathrm{a}} \pm 0.07$ & $8.60^{a} \pm 0.07$ & * \\
\hline 6 week & $9.68^{a} \pm 0.06$ & $5.36^{\mathrm{b}} \pm 0.06$ & $9.32^{a} \pm 0.06$ & $9.57^{\mathrm{a}} \pm 0.06$ & * \\
\hline \multicolumn{6}{|c|}{ Tibia Width (Cm) } \\
\hline 4 week & $0.79^{\mathrm{a}} \pm 0.05$ & $0.48^{\mathrm{C}} \pm 0.05$ & $0.60^{\mathrm{b}} \pm 0.05$ & $0.72^{\mathrm{a}} \pm 0.05$ & * \\
\hline 6 week & $0.98^{a} \pm 0.08$ & $0.51^{c} \pm 0.08$ & $0.88^{b} \pm 0.08$ & $0.92^{a} \pm 0.08$ & * \\
\hline \multicolumn{6}{|c|}{ Tibia Breaking Strength $\left(\mathrm{Kg} / \mathrm{Cm}^{2}\right)$} \\
\hline 4 week & $17.29^{a} \pm 0.93$ & $9.59^{b} \pm 0.91$ & $16.95^{a} \pm 0.89$ & $17.09^{a} \pm 0.90$ & * \\
\hline 6 week & $22.62^{\mathrm{a}} \pm 0.92$ & $9.86^{b} \pm 0.88$ & $21.86^{a} \pm 0.86$ & $22.40^{a} \pm 0.87$ & * \\
\hline
\end{tabular}

$\mathrm{a}, \mathrm{b}, \mathrm{c}$ Means within the same row with different superscripts are significantly different at $P<0.05$, Sig.= Significance, NS= Not significant, * $(P \leq 0.05),{ }^{* *}(P \leq 0.01)$. 


\section{Bone measurements}

Table 5 shows bone measurements, which didn't influenced by decreasing dietary calcium and phosphorus with extra levels of cholecalciferol. Birds fed deficient calcium and phosphorus diet with 3000 I.U gave the worst values compared with other treatments. At 6 weeks of age DTW\% of birds fed either control or 7000 and 8000 were $0.501,0.462$ and $0.490 \%$ respectively without any significant differences, while DTW\% of birds fed deficient diet with 3000 I.U was $0.312 \%$ which was significant low among all experimental treatments. Values of tibia ash, tibia $\mathrm{Ca}$ and tibia $\mathrm{p} \%$ were in the same trend of DTW\%, birds fed deficient diet with 3000 I.U gave the inferior values of ash, tibia $\mathrm{Ca}$ and $\mathrm{P} \%$ among all treatments with significant differences. These results were in harmony with those observed by Santos, $Y$ et al. (2005) who indicated that according tibia breaking strength, bones were stronger in high vitamin $\mathrm{D}_{3}$ diets than control group for treated birds.

Table (5): Effect of low levels of Calcium and Phosphors with different levels of Cholecalciferol on Bone measurements at 4 and 6 weeks of age.

\begin{tabular}{|c|c|c|c|c|c|}
\hline Items & Control & 3000 I.U & 7000 I.U & 8000 I.U & Sig. \\
\hline & & DTW (\%) & & & \\
\hline 4 week & $0.436^{a} \pm 0.002$ & $0.257^{b} \pm 0.004$ & $0.401^{a} \pm 0.002$ & $0.420^{\mathrm{a}} \pm 0.002$ & * \\
\hline 6 week & $0.501^{\mathrm{a}} \pm 0.006$ & $\begin{array}{c}0.312^{b} \pm 0.004 \\
\text { Tibia Ash (\%) }\end{array}$ & $0.462^{\mathrm{a}} \pm 0.006$ & $0.490^{\mathrm{a}} \pm 0.003$ & * \\
\hline 4 week & $42.85^{\mathrm{a}} \pm 0.33$ & $35.21^{b} \pm 0.33$ & $41.89^{a} \pm 0.33$ & $42.12^{a} \pm 0.33$ & * \\
\hline 6 week & $43.12^{\mathrm{a}} \pm 0.22$ & $\begin{array}{l}36.41^{b} \pm 0.48 \\
\text { Tibia Ca (\%) }\end{array}$ & $42.80^{a} \pm 0.40$ & $43.03^{a} \pm 0.53$ & * \\
\hline 4 week & $13.95^{\mathrm{a}} \pm 0.77$ & $9.12^{b} \pm 0.47$ & $13.52^{\mathrm{a}} \pm 0.22$ & $13.60^{\mathrm{a}} \pm 0.52$ & * \\
\hline 6 week & $14.41^{\mathrm{a}} \pm 0.63$ & $\begin{array}{l}9.58^{\mathrm{b}} \pm 0.63 \\
\text { Tibia P (\%) }\end{array}$ & $14.02^{\mathrm{a}} \pm 0.54$ & $14.18^{\mathrm{a}} \pm 0.32$ & * \\
\hline 4 week & $7.50^{\mathrm{a}} \pm 0.21$ & $4.21^{\mathrm{b}} \pm 0.21$ & $6.72^{\mathrm{a}} \pm 0.71$ & $6.99^{\mathrm{a}} \pm 0.11$ & * \\
\hline 6 week & $7.80^{\mathrm{a}} \pm 0.31$ & $4.52^{\mathrm{b}} \pm 0.11$ & $7.01^{\mathrm{a}} \pm 0.11$ & $7.11^{\mathrm{a} \pm 0.12}$ & * \\
\hline
\end{tabular}

\section{Mineral retention}

Table 6 shows mineral retention values of experimental treatments. Birds fed either 7000 or 8000 I.U retain more $\mathrm{Ca}$ and $\mathrm{P}$ compared with control group with significant differences. Values of $\mathrm{Ca}$ retention\% of birds fed control diet, deficient diets with 7000 and 8000 I.U were $44.94 \%, 57.57 \%$ and $59.80 \%$ respectively with significant differences, it was observed that these decrease were dramatically. While birds fed deficient $\mathrm{Ca}$ and $\mathrm{P}$ with $3000 \mathrm{I} . \mathrm{U}$ was the worst in Ca retention\% (37.75\%). The same trend was observed in $\mathrm{P}$ retention\% but it wasn't dramatically like Ca retention\%. These results were in harmony with those found by (Mellanly, 1950; Steenlock and Heirting, 1955) who found that dietary cholecalciferol has long been known to increased phytate phosphors digestibility and reduce the rachitogenic nature of low-ca, high phytate diets. Generally, improvement of PP utilization upon vitamin $D_{3}$ supplementations might be accredited to increased biosynthesis 
and/or activity of intestinal phytase (Shafey et al., 1991), increased phytate hydrolysis by stimulation $\mathrm{Ca}$ absorption making phytate more sensitive to hydrolysis and utilization (Mohammed et al., 1991) or increased P absorption (Wasserman and Taylor 1973; Tanka and DeLuca 1974).

Table (6): Effect of low levels of Calcium and Phosphorus with different levels of Cholecalciferol on Calcium and Phosphors retention.

\begin{tabular}{|c|c|c|c|c|c|}
\hline Items & Control & 3000 I.U & 7000 I.U & 8000 I.U & Sig. \\
\hline \multicolumn{6}{|c|}{ Calcium } \\
\hline Intake & $1.98^{a} \pm 0.02$ & $0.98^{\mathrm{b}} \pm 0.02$ & $0.99^{\mathrm{b}} \pm 0.02$ & $1.02^{b} \pm 0.02$ & * \\
\hline \multirow{3}{*}{$\begin{array}{l}\text { Excretion } \\
\text { Retention } \\
\text { (g) } \\
\text { Retention } \\
(\%)\end{array}$} & $1.09^{a} \pm 0.04$ & $0.61^{b} \pm 0.04$ & $0.42^{\mathrm{c}} \pm 0.02$ & $0.41^{c} \pm 0.03$ & * \\
\hline & $0.89^{a} \pm 0.02$ & $0.37^{c} \pm 0.02$ & $0.57^{c} \pm 0.04$ & $0.61^{b} \pm 0.03$ & * \\
\hline & $\begin{array}{c}44.94^{b} \pm 0.32 \\
(100)\end{array}$ & $\begin{array}{c}37.75^{c} \pm 0.35 \\
(84)\end{array}$ & $\begin{array}{c}57.57^{a} \pm 0.29 \\
(128.1)\end{array}$ & $\begin{array}{c}59.80^{a} \pm 0.23 \\
(133)\end{array}$ & * \\
\hline \multicolumn{6}{|c|}{ Phosphorus } \\
\hline \multirow{4}{*}{$\begin{array}{l}\text { Intake } \\
\text { Excretion } \\
\text { Retention } \\
\text { (g) } \\
\text { Retention } \\
\text { (\%) }\end{array}$} & $1.37^{a} \pm 0.003$ & $0.70^{\mathrm{b}} \pm 0.003$ & $0.74^{b} \pm 0.003$ & $0.73^{b} \pm 0.003$ & * \\
\hline & $0.49^{a} \pm 0.002$ & $0.32^{\mathrm{b}} \pm 0.002$ & $0.25^{\mathrm{b}} \pm 0.002$ & $0.23^{b} \pm 0.002$ & * \\
\hline & $0.88^{a} \pm 0.001$ & $0.38^{c} \pm 0.001$ & $0.49^{b} \pm 0.001$ & $0.50^{\mathrm{b}} \pm 0.001$ & * \\
\hline & $\begin{array}{c}63.23^{b} \pm 0.25 \\
(100)\end{array}$ & $\begin{array}{c}54.28^{c} \pm 0.23 \\
(85.8)\end{array}$ & $\begin{array}{c}66.21^{a} \pm 0.28 \\
(104.7)\end{array}$ & $\begin{array}{c}68.49^{a} \pm 0.31 \\
(108.3)\end{array}$ & * \\
\hline
\end{tabular}

\section{REFERENCES}

AOAC (1990). Association of Official Analytical Chemists. Official methods of analysis $15^{\text {th }}$ Ed. Volume 2, Washington D.C., USA.

Baker DH, Biehl RR and Emmert JL (1998). Vitamin D requirement of

young chicks receiving diets varying in calcium and available phosphorus. British Poultry Science, 39: 413-417

Ballam GC, Nelson TS and Kirby LK. (1985) Effect of different levels of calcium and phosphorus on phytate hydrolysis by chicks.

Nutrition Reports International, 32: 909-913.

Bitar K and Reinhold JG. (1972). Phytase and alkaline phosphatase activities in intetinal mucosa of rat, chicken, calf and man. Biochemistry Bioohysics Acta. 268: 442-452.

Bolu, S. A.; Adebayo, C. A.; Aklilu, A.; Aderolu, Z. (2006). Increasing dietary cholecalciferol for improved broiler marketability .Animal Nutrition and Feed Technology. 6: 2, 223-228.

Davies, M.I., G.M. Ritcey and I. Motzok (1970). Intestinal phytase and alkaline phosphatase of chicks: Influence of dietary calcium, inorganic and phytic phosphorus and vitamin $D_{3}$. Poult. Sci. 49:1280-1286.

Duncan, D.B. (1955). Multiple range and Multiple F tests. Biometrics, 11: 142.

Eardman, JW. Jr and DePaepe M. (1979). Oilseed phytates: Nutritionalimplications. Journal of American Oil Chemist' Society. 56: 736-741. 
Edwards, H. M. Jr. (2002). Studies on the efficacy of cholecalciferol and derivatives for stimulating phytate utilization in broilers. Poult. Sci.. 2002. 81: 7, 1026-1031.

Haq Nawaz; Muhammad Shafiq; Muhammad Yaqoob; Muhammad Yousaf; Fawwad Ahmad (2008). Effect of cholecalciferol on performance and carcass characteristics of broiler chicks. Indian Veterinary Journal.. 85: 8, 851-854.

Kornegay ET, Denbow DM, Yi Z and Ravindram V. (1996). Response of broiler to graded levels of microbial phytase added to maize-soybean meal-based diets containing three levels of nonphytate phosphorus. British Journal of Nutrition. 75: 839-852.

Lofton, J.T., and J.H. Soares Jr. (1986). The effect of vitamin D3 on leg abnormalities in broilers. Poult. Sci. 65:749-756.

Mohamed A, Gibney M. J and Taylor T. G. (1991) The effects of dietary levels of inorganic phosphorus, calcium and cholecalciferol on the digestibilty of phytate-P by the chick. British Journal of Nutrition, 66: 251-259.

Meanby, E. (1950). A story of nutrition research, p. 263 Battimore, Maryland: Williams and Wilkins.

National Research Councel. (NRC). (1994). Composition of poultry feed stuffs. Nat Acad. Sci. Washington, D.C.

Nwokola, EN and Bragg DB (1977). Influence of phytic acid and crude fiber on the availabilty of minerals from four protein supplements in growing chicks.Canadian Journal of ANIMAL science. 57: 475-477.

Onyango EN, Asem Ek and Adeola O.(2006). Dietary cholecalciferol and phosphorus influence intestinal phytase activity in broiler chicken British Poultry Science, 47: 632-639.

Onyango EN, Asem Ek and Adeola O.(2001). Reduction of dietary phosphorus concentration dose not change brush border phytse activity along the smake intestine axis in broiler chicks. Poultry Science, 80 (1): 132-142.

Papesova, L.; Fucikova, A.; Pipalova, M.; Tupy, P (2008) .The synergic effect of vitamin D3and 25-hydroxy-cholecalciferol/calcidiol in broiler diet. Scientia Agriculturae Bohemica. 39: 3, 273-277.

Qian, H., E.T. Kornegay, H.P. Veit, D.M. Denbow and V. Ravindran (1994). Effect of supplemental Natuphos phytase on tibial traits of turkeys fed soybean meal-based semi-purified diets. Poult. Sci. 73(Suppl. 1):89

Rama Rao, S.V., M.V.L.N. Raju, A.K. Panda, P.N. Saharai, M.R. Reddy, G.S. Sunder and R.P. Sharma (2008). Effect of surfeit concentration of vitamin $D_{3}$ on performance, bone mineralization and mineral retention in commercial broiler chicks. The Journal of Poultry Science, 45:25-30.

Rama Rao, S. V, M. V. L. N. Raju, A. K. Panda, G. Shyam Sunder, and R.P. Sharma (2006a) Effect of high concentration of cholecalciferol on growth, mineralization and mineral retention in broiler fed suboptimal concentration of calcium and nonphytate phosphorus. J. Appl. Poult. Res. 15: 493-501. 
Rao, S. V. R.; Raju, M. V. L. N.; Panda, A. K.; Reddy, M. R.(2007) A practical guide to vitamin $\mathrm{D}$ nutrition in poultry .Poultry International. 46: 6, 12-16

Rio Garcia, J. C. del; Avila Gonzalez, E.; Casaubon Huguenin, M. T.; Rosiles Martinez, R.; Ledesma Martinez, N.; Petrone, V. M.; Moreno Martinez, E.(2006). Effect of 25-hydroxycholecalciferol in presence of aflatoxin B1on the performance of broiler chicken. REDVET. 2006. 7: 12, 120604. (Abstr)

Santos, Y.; Soto-Salanova, M. F. (2005). Effect of Hy-DReg. addition on performance and slaughterhouse results of broilers. Proceedings of the 15th European Symposium on poultry nutrition, Balatonfured, Hungary, 25-29 September, 2005. 219-221.

SAS Institute. (1996). Statistical Analysis System, SAS User's Guide: Statistics. SAS Institute. Inc.Editors, Cary, NC. USA.

Schoner FJ, Hoppe PP, Schwarz G and Wieshe H. (1993). Phousphorus balance of layers supplied with phytase from Asperigllus Niger. In: Vitamine und weitere zusalzsoffe Bei Mensh Tierk Supoosium (Flachowsky G and Schubert R eds.) Poultry Abstract 20: 287.

Shafey TM, McDonald MW and Pym RAE. (1990) Effects of dietary

calcium, available phosphorus and vitamin $D$ on growth rate, food utilization, Plasma and bone constituents and calcium and phosphorus retention of commercial broiler strains. British Poultry Science, 31: 587-602.

Steenbock, H and Herting, D. C. (1955). Vitamin D and growth. Journal of Nutrition, 57: 448-458.

Tanka, Y. and H.F. DeLuca (1974). Role of 1,25-dihydroxyvitamin $D_{3}$ in maintaining serum phosphorus and curing rickets. Proc. Nat. Acad. Sci. U.S.A. 71:1040-1044.

Wasserman, R.H. and A.N. Taylor (1973). Intestinal absorption of phosphate in the chick. Effect of vitamin $\mathrm{D}_{3}$ and other parameters. J. Nutr., 103:586-599. 
Thabet, H. A. et al.

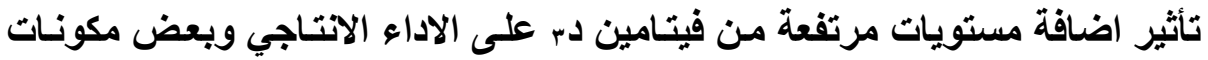

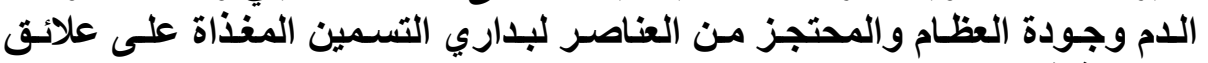

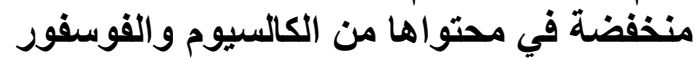

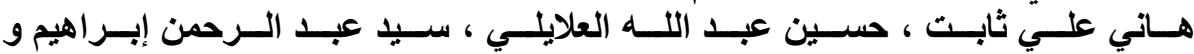

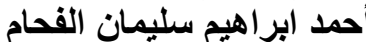
قسم انتاج الدواجن ـ كلية الزراعة ـ جامعة عين شمس ـ شبرا الخيمة ـ القاهرة ـ مصر

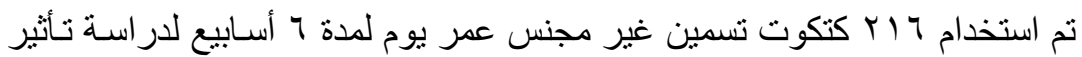

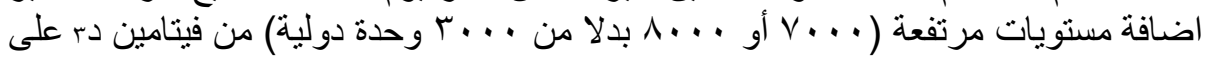

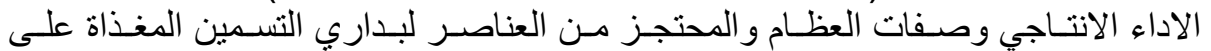

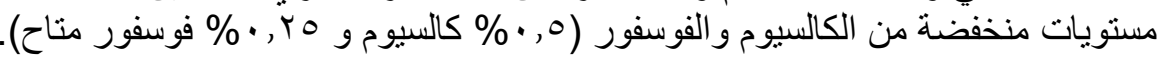

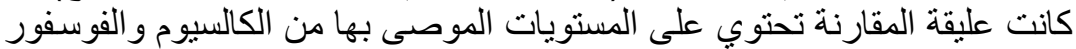

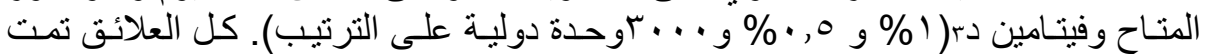

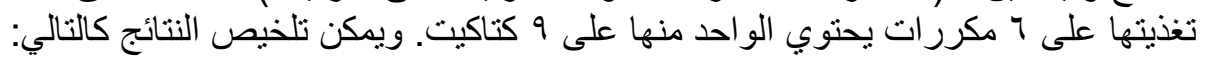

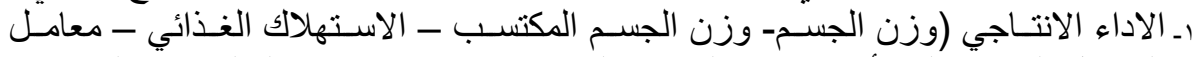

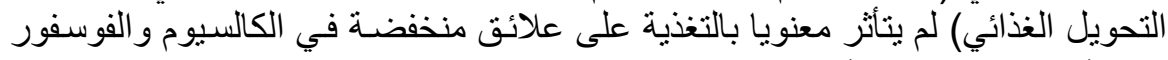

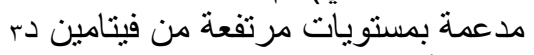

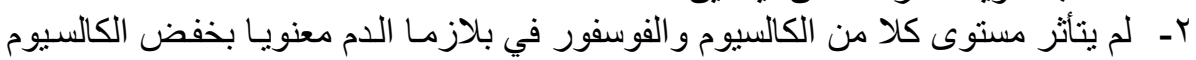

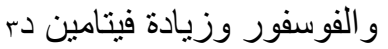

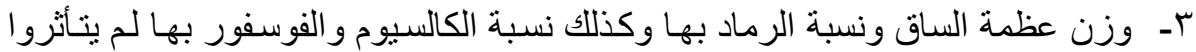

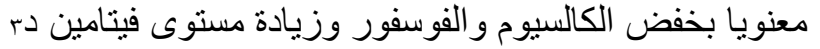

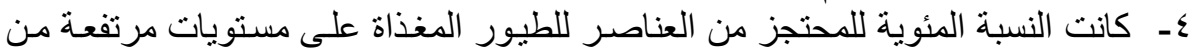

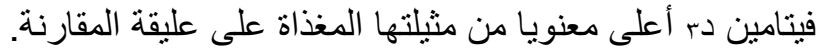

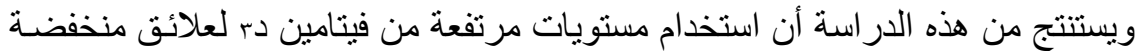

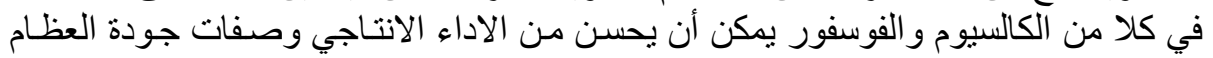

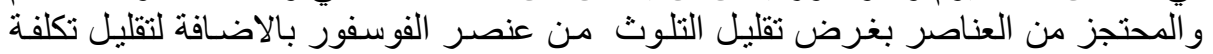
التغذية.

كلية الزراعة - جامعة المنصورة كلية الزراعة - جامعة كفر الثيخ الثورة
قام بتحكيم البحث أ. أد / ترك محمد البر ابر اهيم درة

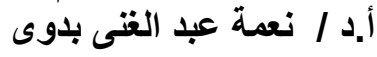


J. Agric. Sci. Mansoura Univ., 34 (12), December, 2009 
Thabet, H. A. et al. 